\title{
Ołtarz Zbigniewa Herberta - wiersz, styl, semantyka
}

ABSTRACT. Bodusz Marek, "Otarz" Zbigniewa Herberta - wiersz, styl, semantyka ["Ołtarz" by Zbigniew Herbert - line structure, style, semantics]. „Przestrzenie Teorii” 9. Poznań 2008, Adam Mickiewicz University Press, pp. 193-203. ISBN 978-83-232-1917-0. ISSN 1644-6763.

In this text I present the poem by Zbigniew Herbert "Ottarz" as a text whose style and line structure refer to "Bema pamięci żałobny rapsod" by Cyprian Kamil Norwid. The poem from 19th century puts a special meaning as "the most outstanding realisation of Polish hexameter" to contemporary works. The hexameter that comes from ancient tradition (Homer) evokes associations connected with it: seriousness, pathos and also the distance to described events. Using the hexameter is an important clue of an author who gives information about understanding of innate " $I$ " expression on the level of style, rhythm and line structure of a poem ("a gesture" of restriation to regular form).

Such poetic strategy gives Herbert a possibility of expressing his pessimistic and ironic opinions about art - "self-possessed poet" has a possibility of artistic object description which is not "a monument impossible to be destroyed", on the contrary - it is an object that is under the destructive power of time.

Jesteśmy ogniwem wielkim tańcuchu tradycji.

Zbigniew Herbert

Oltarz Zbigniewa Herberta przywołuje i uobecnia w przestrzeni wiersza współczesnego wiersz Cypriana Kamila Norwida Bema pamięci żałobny-rapsod. Odsyłają do romantycznego źródła nie tylko rytmiczne wersy tutaj powtórzone, ale także wizja pochodu ofiarnego wpisane $\mathrm{w}$ „najwybitniejszą dziewiętnastowieczną realizację oryginalną [...] polskiego heksametru” 1 . W tym ujęciu można więc mówić o znaczącym „te-

${ }^{1}$ L. Pszczołowska, Wiersz polski, Wrocław 2001, s. 218. Autorka uznaje Bema pamięci żalobny-rapsod Norwida za najwybitniejszą w wierszu XIX wieku realizację heksametru: „Będzie on [heksametr polski - dod. M.B.] się wiązał ze stylem wysokim. Takie konotacje ma też heksametr w najwybitniejszej swojej XIX-wiecznej realizacji oryginalnej (tj. nie w utworze tłumaczonym), w wierszu Bema pamięci żalobny-rapsod. W rytmie heksametru porusza się kondukt pogrzebowy współczesnego bohatera narodowego, przedstawiany jako powolny i uroczysty pochód obrzędowy za zwłokami prasłowiańskiego woja. W takim kontekście heksametr nabiera wartości znakowej, współtworząc powage i wzniosłość; Także Adam Kulawik akcentuje nowatorstwo heksametru w wersji Norwida: „Norwida trzeba uznać za twórcę naszego nowego heksametru”, „Dopiero w 1851 roku, pisząc Bema pamięci żalobny-rapsod stwarza heksametr, jakiego dotąd nie było. Oparł go bowiem na wydoskonalonym tymczasem systemie wiersza sylabotonicznego [...]. Użył go poeta w niespotykanej dotąd funkcji lirycznej, zarzucił stychomię, zrytmizował, tworząc 
rytorium podwójnego bytowania" formy antycznej (z ewokowanymi przez nią treściami wysokiego stylu i postawy), którą bierze dziewiętnastowieczny poeta i którą ponawia teraz poeta współczesny. Tak uzyskane trwałe zespolenie głosów nabiera $\mathrm{w}$ wypowiedzi Zbigniewa Herberta szczególnego znaczenia, zwłaszcza wówczas, gdy ma służyć współtworzeniu powagi i wzniosłości:

Naprzód szły elementy: woda muły niosąca ziemia o oczach mokrych ogień żarłoczny i skory potem trzęsąc grzywami łagodne szly smoki powietrza tak otwierały procesję dla kwiatów i roślin małych przeto trawę wychwala dłuto artysty Zielony płomień nieludzki jak płomień rzucany z okrętów trawę która przychodzi kiedy historia się spełnia i jest rozdział milczenia

tupot zwierząt ofiarnych żegna Tellus wilgotną idą cielesne i jasne na szyjach ciepło niosące i nieświadomość losów na czołach znaczonych rogami upadną na przednie kolana krwią własną znaczonych rogami Wołają ciebie żywioły zwierzęta drogę otwarły rozstąpi się niebo przed tobą i Bóg przemówi piorunem człowieku bardzo mizerny i bardzo godny pogardy lecz uniesiony wysoko na grzebiecie ziemskich gatunków

tu przerwa jest w płaskorzeźbie - jeżeli umiesz to domyśl może ofiara była niemiła bogom wieczystym lub wilgoć niechętna trwaniu zdjęła kształty człowiecze sandal $i$ kawal stopy bogini Ironii ich strzegła a także fałdów szaty, po których łatwo odczytasz gest ramion pięknie wzniesionych $i$ to naprawdę wszystko rąk nie bylo grających na rogach zwierząt ofiarnych

nie wiesz jakie twe słowo $i$ jaki kształt może błahy przechowa zmarszczka kamienia - nie to co myślisz że tobą i nie wiesz czy krew i kości i może rzęsę wybiorą w ziemi ułożą łaskawej gdzie dojrzewają posągi

[Z. Herbert, Ottarz]

układy zwrotkowe [...]. Zjawia się przerzutnia [...], ale nie rozregulowuje ona rytmu heksametrowego, gdyż ten wspiera się dodatkowo o rym" (A. Kulawik, Heksametr polski arka przymierza między starymi a nowszymi systemami wersyfikacyjnymi, w: Metryka stowiańska, red. Z. Kopczyńska, L. Pszczołowska, Wrocław 1971, s. 168); Podobnie „heksametr Norwidowski” odczytuje Mikołajczak: „W odróżnieniu od heksametru polskiego Mickiewicza był on [wzorzec Norwida - dod. M.B.] wierszem ściśle sylabicznym, dopuszczal tok przerzutniowy oraz amfibrach w pierwszej stopie pośredniówkowej. Heksametr Norwidowski rezygnuje przy tym ze stychomytii, operuje strofą i rytmem" (M. Mikołajczak, „W cieniu heksametru...”. Interpretacje wierszy Zbigniewa Herberta, Zielona Góra 2004, s. 32). 
Sześcioakcentowiec z jawnymi aluzjami do stylistycznych cech heksametru Norwida, czyli - jak mówi Mikołajczak - szczególnej formy dającej możliwość przedstawienia „miarowego, powolnego kroku uczestników żałobnego pochodu"' jest tu wykładnią ściśle określonych treści i tematów. Aluzje wersyfikacyjne do norwidowskiego wiersza szczególnie widoczne są w 5 . i 7. wersie pierwszej części poetyckiej wypowiedzi Herberta - mamy tu dokładne powtórzenie 15-zgłoskowca $z$ średniówką po 7. sylabie na granicy 3. i 4. stopy (tok daktyliczny w pomieszaniu $\mathrm{z}$ trocheicznym) $)^{3}$ :

5. przeto trawę wychwala dłuto artysty Zielony

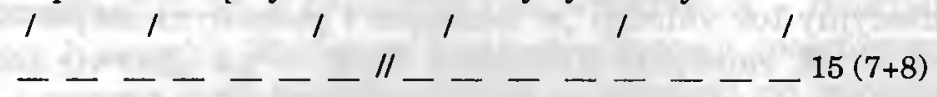

7. trawę która przychodzi kiedy historia się spełnia

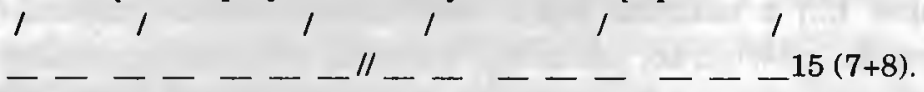

Zbliżony do formy heksametru Norwida porządek akcentowy obserwujemy też w pozostałych wersach pierwszej strofy wiersza Herberta, na przykład:

1. Naprzód szły elementy: woda muły niosąca

$\begin{array}{ccccc}/ & / & / & / & / \\ - & - & - & - & -\end{array}$

2. ziemia o oczach mokrych ogień żarłoczny i skory

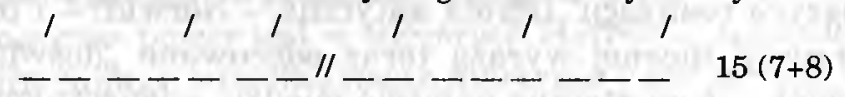

3.potem trzęsąc grzywami łagodne szły smoki powietrza

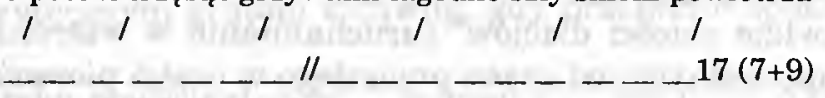

${ }^{2}$ M. Mikołajczak, op. cit., s. 32.

${ }^{3}$ M. Dłuska zwraca uwagę na to, ze „kłócące się" w heksametrze trocheje i daktyle mogą „wtrącić" odbiorcę w tok trocheiczno-amfibrachiczny: „Tok daktyliczny w pomieszaniu $\mathrm{z}$ trocheicznym [...] ma [...] i pochodny od heksametru 15-zgloskowy wiersz sylabotoniczny [...]. Wobec nieszczęsnego występowania zestrojowych daktyli, a jeszcze rzadszej możliwości utylizowania ich w wierszach, ich tok krzyżowany, zwłaszcza, gdy się mieszają z trochejami i występują $z$ odbitką, prowadzi do zamącenia daktylicznego wzorca, i przy nie zmienionym rozkładzie akcentów wtrąca nas w tok trocheiczno-amfibrachiczny, odrywając wiersz od antycznego wzoru [podkr. - M. B.]" (M. Dłuska, Sylabotonizm, w: tejże, Studia z historii i teorii wersyfikacji polskiej, t. II, Warszawa 1978, s. 76). Por. z Bema pamięci żalobnej-rapsodem Norwida:

1. Cžmu, Cieniu odjeżdżasz, ręce złamawszy na pancerz

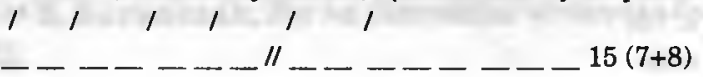


Powtórzenie (dokładne albo sparafrazowane) rytmicznego toku wiersza Norwida daje Herbertowi możliwość odzwierciedlenia „miarowego, majestatycznego dynamizmu świata w powolnym ruchu elementów" 4 (wody, ognia, ziemi, powietrza, roślin i zwierząt) - przez co wzmacnia jednocześnie wizje „odwiecznego ładu”, czyli uniwersalizmu opisywanego kosmicznego rytmu (od narodzin do śmierci5). Zwraca uwagę Przemysław Czapliński, iż obrazy świata w twórczości Herberta „ukazywane są z perspektywy kosmicznej”, a „holistycznym ujęciom dziejów towarzyszy skłonność do patosu i profetyzmu, podniosłości tonu odpowiada klasycyzująca fraza wiersza"

Inkantacyjny tok składni „w ciemnym i powolnym zaśpiewie płynący”, oparty - jak zauważył Kazimierz Wyka - na „kanwie tonicznego sześcioprzyciskowca, polskiej aluzji do heksametru”, a także „patetyczne obrazowanie [...] z samych pojęć ostatecznie złożone: elementy, woda, ziemia, smoki, powietrze, płomień, historia, milczenie, rozdział milczenia" - są tu swoistymi narzędziami opisu świata w perspektywie kosmologicznej. Dzięki użyciu tych „rekwizytów” tekst nabiera patetycznej wzniosłości. Metr toniczny wiąże się też $\mathrm{z}$ opanowaniem emocji i tym samym dobrze służy wypowiedzi o poważnych treściach ${ }^{8}$.

Herbert używa więc heksametru polskiego, by silniej zaakcentować powagę i wzniosłość tematu własnej wypowiedzi (metryczna stylizacja na formę "wysoką" jest sygnałem „podwyższenia rangi” stylu). Przywołany aluzyjnie heksametr wnosi bowiem do wypowiedzi współczesnej „pamięć wcześniejszych realizacji" (strofa antyczna - Norwid) - i przez nawiązanie do tradycji dawnej wyraża teraz odczuwane "doświadczenie tragiczne" podmiotu (dramatyczne napięcie między „odwiecznym ładem” a jednostkowym niepokojem) 9 .

Herberta „wizja całości dziejów” (uruchamianie w wierszu różnych przypadków temporalnych: od czasu przeszłego w części pierwszej, przez teraźniejszy w części pierwszej i drugiej, aż po sytuację liryki projektującej w czasie przyszłym) - znaczona jest współistnieniem wartości trwałych i przemijających, „wysokich” i „niskich”. Można więc - za Mikołajczak - powiedzieć, że „patos i wzniosła retoryka, obrazowość i dyskursywność, epickość i liryzm, katastrofizm i motywy genezyjske, sztuka

${ }^{4}$ M. Mikołajczak, op. cit., s. 69-70.

${ }^{5}$ Zob. tamże.

${ }^{6}$ P. Czapliński, Smierć, czyli o nieskończoności, w: Poznawanie Herberta, op. cit., s. 282-283.

${ }^{7}$ K. Wyka, Skladniki świetlistej struny, w: Poznawanie Herberta, wybór i wstęp A. Franaszek, t. I, Kraków 1998, s. 26.

${ }^{8}$ M. Mikołajczak, op. cit., s. 70.

${ }^{9}$ M. Mikołajczak, op. cit., s. 54 . 
i natura, a wreszcie jednostka i zbiorowość splatają się tu w symbolicznym, trudnym do przełożenia na język literatury "obrazowaniu»"10.

Ponowienie heksametru jest wskazówką autora, który już na poziomie rytmiki i wersyfikacji wiersza (,gest” zamknięcia w regularnej formie) daje informację o opanowaniu ekspresji wewnętrznego ,ja" (panowanie nad żywiołem mowy). Stąd bierze się w jego wypowiedzi „epicki (antyczny) dystans" wobec opisanego (i przeżytego) doświadczenia sprzeczności świata.

Sztuka staje się planem nadrzędnym „boskiego porządku” czasu i przestrzeni, ukazanego $\mathrm{w}$ procesie od genezis do katastrofy (,przerwa w płaskorzeźbie")11. Stąd przedstawione wydarzenia - rozwijane lirycznie według hierarchii Wielkiego Łańcucha Bytów ${ }^{12}$ (powtórzmy: od elementów najprostszych: żywioły, rośliny i zwierzęta do człowieka „uniesionego wysoko na grzbiecie ziemskich gatunków" i stojącego nad nim Boga) - należy czytać nie tyle w porządku chronologicznym, ile raczej w ich przestrzennym usytuowaniu. Można więc powiedzieć, że tematem wiersza nie jest opis „dziejów świata” (od arkadii do zagłady z nadzieją ponownego powrotu do „Raju Utraconego”: genezis-apokalipsa-genezis), lecz proces powstania dzieła sztuki, której ład jest odbiciem kosmologicznego porządku świata.

Przejście od opisu przedmiotu do „perswazyjnego" kształtu wiersza pozwala poecie oddziaływać $\mathrm{w}$ jeszcze inny sposób ${ }^{13}$, bowiem obcowanie z przestrzenia dzieła-płaskorzeźby daje mu możliwość wyrażenia tego, co jest niedostępne słowu „bezczasowości”. Przy czym zwraca się też uwagę, że właśnie czas pojęty jest w wierszach Herberta ,jako niepowstrzymana siła, która rujnuje wszelkie nasze marzenia o stworzeniu uniwersalnego, wiecznotrwałego dokonania kulturowego: każdy $\mathrm{z}$ naszych tworów staje się bezużytecznym gratem $\mathrm{z}$ chwilą, gdy przeminie epoka, która go wydała"14.

„Poetyka powściągliwości i milczenia” - jak rzecz nazywa Herbert a więc budowanie wypowiedzi z jednoczesnym opanowaniem ekspresyj-

10 Tamże, s. 155 .

11 Zob. tamże, s. 160. Także w wierszu Glos Herbert wskazuje na bezradność człowieka w rozumieniu „porządku” świata, którego przeznaczeniem jest chaos - „niezrozumiałe gulgotanie".

12 Termin wziąłem od A.O. Lovejoya, Wielki Łańcuch Bytu. Studium z dziejów idei, Warszawa 1999; por. J. Abramowska, Wiersze $z$ aniolami, w: Poznawanie Herberta, op. cit., t. II, Kraków 2002, s. 168-169.

13 B. Carpenter, Zbigniewa Herberta lekcja sztuki, w: Poznawanie Herberta, op. cit., t. II, s. 229: „Malarstwo i inne sztuki wizualne funkcjonują w przestrzeni, słowa natomiast w czasie".

14 S. Barańczak, Pot na marmurze, w: tegoż, Ironia i harmonia, Warszawa 1973, s. 125 . 
nego "ja» barbarzyńcy” jest czymś wyjątkowym i z niczym nieporównywalnym ${ }^{15}$. W tym kontekście owe Herbertowskie „rozdziały milczenia” byłyby znakiem panowania nad słowem-ekspresją, a jednocześnie znakiem przywracania przytoczonemu dziełu charakteru ponadczasowego. Heksametr ma takie wartości uwydatniać: podkreśla tonację, w jakiej podmiot przedstawia temat i - jak mówią Kopczyńska z Pszczołowską w naturalny sposób „wyraża mowę trudną, dobitną, opanowaną, o wyrównanej linii emocjonalnej"16.

Dokładne powtórzenie heksametru polskiego (wersy 5. i 7.) realizuje się także razem z przywołaniem motywu dłuta, co ma symbolicznie uobecnić $\mathrm{w}$ przestrzeni między wierszami (Norwid-Herbert) obraz „artysty-rzeźbiarza", którego praca istotnie wpływa na kształt rzeczywistości. Ta zwielokrotniona perspektywa staje się ponownym otwarciem rozważań nie tylko nad trwałością i przemijaniem dzieł artystycznych, ale również nad ofiarą i cierpieniem artysty. Widoczna w tym miejscu wspólnota myśli Norwida/Herberta ujawnia (jak się okaże w dalszej części wiersza - nieskutecznie) swego rodzaju „zgodność widzenia” sztuki jako wartości ocalającej ${ }^{17}$.

$\mathrm{Z}$ kolei podsunięty już w tytule wiersza Herberta trop interpretacyjny przywołuje eschatologiczną perspektywę ujmowania rzeczy i daje informację o konieczności odbioru jego treści w religijno-etycznej aksjologii. Także temat „artysty cierpiącego" (ofiara jako cierpienie) - twórcy „porządku sztuki" ponad "chaosem życia"18 - jest nawiązaniem do norwidowskiej koncepcji „piękna, które po to jest, by zachwycało”, „pracy - by się zmartwychwstało" (Promethidion). Jest w tym powtórzona idea sztuki jako przymierza Boga z człowiekiem (artystą). Herbert jednak biorąc

${ }_{15}$ M. Sugiera, Barbarzyńca w ogrodzie kultury, w: Poznawanie Herberta, op. cit., s. 67-68. Por. z innym wysłowieniem Ryszarda Przybylskiego: „W istocie rzeczy człowiek jest antynomią cierpienia, które nadaje mu formę, i komunikacji, która go jej pozbawia” (R. Przybylski, Między cierpieniem a formq, w: Poznawanie Herberta, op. cit., t. I, s. 101).

16 Z. Kopczyńska, L. Pszczołowka, Heksametr polski. Wtaściwości rytmiczne i funkcje znakowe, „Pamiętnik Literacki” 1983, z. 2.

${ }_{17}$ Por. z wierszem Z. Herberta Do Ryszarda Krynickiego - list. Poeta stwierdza tu, że: „uwierzyliśmy zbyt łatwo, że piękno nie ocala”.

18 Zob. M. Mikołajczyk, op. cit., s. 155. Autorka stwierdza, że „rzeczywistośc fizyczna" (życie człowieka) ma u Herberta charakter „chaotyczny”; Podobnie rzeczywistoś kreowaną w twórczości Herberta postrzega Czapliński: „Rzeczywistość nie tworzy ładu bo jej normalność jest podejrzana albo, jak w utworze Hotel (HPG), "niewiarygodna", bo katastrofa dostrzega w niej znaki nadchodzącej zaglady; wzorem niezmienności, układem wiecznotrwałym nie jest również kosmos" (P. Czapliński, Śmierć, czyli o niedoskonatości, w: Poznawanie Herberta, op. cit., t. I, s. 288-289). 
temat od Norwida i wpisując go w nowy kontekst wiersza współczesnego, projektuje jednocześnie różnicującą semantykę:

Dla Norwida Bóg byl Miłością. Piękno zaś stanowiło zewnętrzny przejaw boskości, a zatem w naturalny sposób emanowało również z miłości. W widoczny sposób Bóg bowiem objawial się na ziemi w pięknie. Natura jest piękna, bo jest dziełem Boga i zawiera w sobie boskość Stwórcy [...] Piękno jest więc jednocześnie „kształtem Miłości” i „profilem Bożym” [...] Miłość i boskość stają się zatem w sposób oczywisty tożsame. Piękno zaś jest ich widomym przejawem. Człowiek jest zdolny do tworzenia piękna, bo ma w sobie element boski ${ }^{19}$.

U Herberta nie ma jednak - jak to było w utworze Norwida - „Tęczy wiecznej Jeruzalem" (Promethidion): człowiek musi przyjąć postawę „ofiary przebłagalnej” wobec Boga, który „przemówi piorunem” (narzędzie kary). Motyw ofiary jako wznioslego gestu wobec Boga wzmacnia dodatkowo podniosły styl wypowiedzi (stylizacja na język biblijny), z użyciem słownictwa typu: „przeto”, „,spełnia się”, „żegna”, „zastąpi się niebo”. Cierpieniem artysty nie jest jednak - jak u Norwida - poczucie osamotnienia wynikające $\mathrm{z}$ braku akceptacji przez współczesnych (twórcageniusz i dzieło wyprzedzające tendencje estetyczne i światopoglądowe epoki), lecz wynika ono z niepewności, której źródłem jest świadomość śmiertelności człowieka i sztuki20. Kondycję człowieka „bardzo mizernego i bardzo godnego pogardy” określa teraz słownictwo typu: „może”, „nie wiesz", "nie to co myślisz", ,jeśli wiesz" - ewokujące zwątpienie i brak pewności ${ }^{21}$.

Przywołanie postawy Norwida, który używa toposu exegi monumentum aere pereunius („pomnika niezniszczalnego”) jest też przywołaniem klasycznego toposu nieśmiertelności i przyszłej sławy artysty"22, tyle że w innej niż klasyczna wersji (topos odwrócony):

19 E. Szymanis, "Odpowiednie dać rzeczy stowo" - norwidowska teoria sztuki w praktyce poetyckiej, w: Norwid z perspektywy XXI wieku, red. J. Rohoziński, Pułtusk 2003, s. 120.

20 „Herbert, choć światopoglądowo najbliższy Camusowskiej tradycji «heroizmu istnienia", nie mieści się więc w egzystencjalizmie bez reszty. Różnica polega na tym, że dla egzystencjalistów wartością bronioną byla autentyczność, a jedyną reakcją na śmierć poczucie absurdu istnienia, dla Herberta zaś wartością jest rytualność, a postawą wybieraną wobec śmierci - pochwala śmierci" (P. Czapliński, op. cit., s. 303). Podobnie stwierdza Abramowska: „Istotą tego, co ludzkie, jest u Herberta niedoskonałość, śmiertelność i podatność na cierpienie" (J. Abramow ska, op. cit., s. 170).

${ }^{21}$ „Ścieżka cierpienia jest u Herberta splątana ze ścieżką życia: nasze istnienie jest niekonieczne, nasza tożsamość niepewna, a nasz koniec bezzasadny, lecz nieunikniony. W świecie Herberta żyje się więc i umiera bez racji - życiem wychylonym ku nicości i nie dysponującym żadną oczywistą wartością, którą można by przeciwstawić śmierci. Śmierci wszechobecnej i wieloimiennej" (P. Czapliński, op. cit., s. 280).

22 S. Stabryła, Wstęp do: Horacy. Dwadzieścia dwie ody, przeł. A. Ważyk, oprac. S. Stabryła, BN II, nr 232, Wrocław 2004, s. CLXXI. 
W koncepcji Norwida piękno ma więc poprzez ukazywanie wartości Boga zachęcać do pracy nad sobą dla osiągnięcia zbawienia. Prawdziwa sztuka ujawnia bowiem kształt boskości. W muzyce Szopena „Emanuel już mieszka/ Na Taborze!”: (I, s. 499). Sztuka pozwala więc zbliżyć się do największej tajemnicy [...]. Jednak: „Pięknem globu tego - niedostatek” (I, s. 499). Przemienienie na górze Tabor trwało chwilę. Muzyka też nie trwa wiecznie. Do doskonalości można się zbliżać, ale nie można jej osiągnąćc ${ }^{23}$.

Kontrasytwne zestawienie semantyki stylu klasycznego z przedstawieniem dzieła (płaskorzeźba), które nie może przetrwać „kataklizmu historii" w postaci niezmiennej, trwałej, wzniosłej i z niepewnym losem artysty, który nie wie

\author{
jakie [...] słowo i jaki kształt może błahy \\ przechowa zmarszczka kamienia [...] \\ czy krew i kości i może rzęsę wybiorą \\ w ziemi ułożą łaskawej gdzie dojrzewają posągi
}

świadczy o tym, że norwidowska formuła sztuki, która nie jest doskonała znajduje w wierszu Herberta potwierdzenie.

Trop interpretacyjny poddaje też zmiana tonacji „głosu” poety współczesnego: od tonacji patetycznej do ironicznej. W ten sposób uwidoczniony efekt polemicznej konwersacji ze wzorcem klasycznym uzyskuje Herbert w wyniku - jak rzecz określa Elżbieta Dąbrowska - „strukturalnoznaczeniowej koncepcji naśladowania w pewien sposób "cudzego głosu»": od "stylizacji akcpeptatywnej” do „dystansującej”24. W drugiej części wiersza dzieło sztuki zmienia swój charakter, przestaje być „wielkie”:

wilgoć niechętna trwaniu zdjęła kształty człowiecze

sandał i kawał stopy bogini Ironii ich strzegła

a także fałdów szaty

„Bogini Ironii - stwierdza Stanisław Barańczak - ocala przeszłość i strzeże jej przed zagładą: jednakże ocala - co właśnie jest ironiczne jedynie przypadkowe fragmenty tej przeszłości, z których całość można dopiero mozolnie rekonstruować. Ironia jest więc tutaj rozumiana jako „obiektywna, niezależna od czyjegokolwiek świadomego zamiaru przypadkowość dziejów i ludzkiej pamięci"25.

Dokonania kulturowe przeszłości nie mogą przetrwać w całości, gdyż sztuka jest wpisana w sferę świata ludzkiego, a więc przynależy do porządku nietrwałego, przemijającego, a nie - jak u klasyków - boskiego,

${ }^{23}$ E. Szymanis, op. cit., s. 121.

${ }^{24}$ E. Dąbrowska, Stylistyka intertekstualna a efekt parodii, w: Świat humoru, red. S. Gajda, D. Brzozowska, Opole 2000, s. 557.

${ }_{25}$ S. Barańczak, Uciekinier z utopii. O poezji Zbigniewa Herberta, Wrocław 1994, s. 153 . 
czyli trwałego 26 . Stąd jest - jak owy „kruchy” świat - jest „okaleczona”, „umierająca”, a jej „kształt musi dojrzeć na nowo, przejść próbę wody, powietrza i ognia, odrodzić się z drobiazgu, fragmentu przechowanego w ziemi łaskawej"27.

Poświadczenie tego przekonania odnajdziemy w innym wysłowieniu Herberta: „w ogrodzie sztuki znajduje się wielki szpital form okaleczonych i umierających. Podobnie jak chorzy, oczekują one naszego współczucia i zrozumienia"28. Struktura demaskacyjna, jaka wytwarza się w Oltarzu przez kontekst przywołania stylu historycznego, narusza więc ustalony porządek i akceptowany dotychczas język wartości tradycyjnych (dekonstrukcja mitu literackiego). Postawa ironiczna Herberta, która oznacza zdystansowanie się wobec zarówno profetycznego patosu (katastrofizm) ${ }^{29}$, jak i „łatwego” optymizmu (powrót do „Raju Utraconego"), powoduje „odwrócenie i zanegowanie modelu tradycji”30:

i nie wiesz czy krew i kość i może rzęsę wybiorą.

Istotne dla semantyki Oltarza jest to, że aktualizacja stylu klasycznego wpisana jest w ironiczny „głos” poety współczesnego. „Aktualizacja akceptatywna" postawy klasycznej, jaką obserwujemy w pierwszej części wiersza Herberta, zostaje w dalszych fragmentach porzucona i poeta współczesny prowadzi teraz spór ze wzorcem, wykorzystując go jako punkt wyjścia (pre-tekst) do przedstawienia własnej, odmiennej racji. Można powiedzieć, że Herbert projektuje „lekturę dwutekstową” (dwukulturową), w efekcie której widać zderzenie różnych postaw (postawa Herberta i klasyczna) i różnicę znaczeń. „Zdemaskowany” przez ironię topos staje się teraz funkcją degradacji i demitologizacji wiary w „nieśmiertelność sztuki (i życia)" (międzykulturowa opozycja i naruszanie „uświęconego" porządku mitu).

Już sama obecność ironicznej nuty w tekście Herberta wyraża „stosunek wartościujący z pejoratywnym akcentem"31. Można więc powie-

20 O ile u Norwida „piękno jest profil Boży” (Promethidion), o tyle u Herberta. stwierdza Abramowska - „doskonałość oznacza porządek «martwy», obcy rozwichrzonemu chaosowi, nieprzewidywalności i stałemu zagrożeniu, które są udziałem i właściwością życia" (J. Abramowska, op. cit., s. 172).

${ }^{27}$ Mikołajczak, op. cit., s. 168.

${ }^{28}$ Z. Herbert, Labirynt nad morzem, „Twórczość 1973, nr 2, s. 11.

29 „Katastrofiści rzadko kiedy kończą na opłakiwaniu ruin i zwykle dochodzą [...] do postawy heroicznej i tylko dzięki temu odnajdują wreszcie swoje miejsce w ciągu kulturowym" (J.M. Rymkiewicz, Czym jest klasycyzm? Manifesty poetyckie. Warszawa 1967, s. 69).

${ }^{30}$ Zob. E. Dąbrowska, op. cit., s. 559

31 Tamże, s. 559. 
dzieć, że akceptacja i aneksja semantyki powtórzonej frazy heksametru w pierwszej części Oltarza, zostaje w kolejnych fragmentach odwołana, a ostateczna informacja, jaką daje Herbert, powstaje w intertekstowej przestrzeni: między kwalifikacją użytej przez niego kultury klasycznej („wspólny świat kultury”), a odczytaniem jej w różnicującej semantyce "oryginału”. Stąd to, co wydawało się na początku tekstu „aktywną kontynuacją", okazuje się w efekcie finalnym "stylizacją dystansującą". W takim kontekście cały pierwszy fragment Oltarza (z tonacją patetyczną) odczytany jest jako mistyfikacja, natomiast część druga (z tonacją ironiczną), która bierze część pierwszą w nawias - jest demaskowaniem owej mistyfikacji32.

Kulturowy topos przeniesiony bezpośrednio do wypowiedzi Herberta, wchodzi w określoną „grę" intertekstualną. Poeta przygotowuje najpierw grunt (prezentuje temat $w$ stylu patetycznym), by tym silniej zderzyć style wypowiedzi i zdemaskować temat.

Zbigniewa Herberta strategia „demaskowania mistyfikacji” na terenie wiersza daje możliwość artykulacji świata i jego interpretacji właśnie poprzez strategię powtórzenia stereotypów myślowych (toposy) po to, by następnie zdystansować się względem nich przez chwyt kontradykcji. Spełnia się tutaj poetycki program autora Ottarza polegający na „godzeniu człowieka z rzeczywistością” przez pokazanie właściwości „rzeczywistości konkretnej”, w zdemitologizowanej „wierności rzeczy”:

Naszym zadaniem nie jest rozwiązywanie zagadek, ale uświadamianie ich sobie, pochylanie glowy przed nimi, a także przegotowanie oczu na nieistniejący zachwyt [...]. Moje zadanie [...] polega [...] na godzeniu czlowieka $z$ otaczającą rzeczywistością33.

Sferą działalności poety [...] nie jest współczesność, ale rzeczywistość, uparty dialog człowieka $z$ otaczającą go rzeczywistością konkretną [...], kultywowanie zanikającej umiejętności kontemplacji [...], wierność rzeczy ${ }^{34}$.

Przedstawienie rzeczywistości „naznaczonej śmiercią” i ironiczny dyskurs wobec trwałości dokonań kulturowych są w rezultacie waloryzowaniem pozytywnym, gdyż wyrażają postawę „współczucia i zrozumienia" wobec „form okaleczonych i umierających". Jest bowiem tak jak mówi Czapliński - że: „bez śmierci nie byłoby [...] ani współczucia, ani piękna, ani sensu"35. Herbert przywołuje więc toposy „dzieła trwałego" i „nieśmiertelności artysty”, by wypowiedzieć się na temat sytuacji

32 S. Balbus, op. cit., s. 318.

33 Z. Herbert, Apokryfy holenderskie, "Twórczość" 1979, nr 7, s. 22.

34 Z. Herbert, Poeta wobec wspótczesności, „Odra" 1972, nr 11, s. 49.

35 P. Czapliński, op. cit., s. 303. 
egzystencjalnej człowieka. W jego ujęciu wartością ,ja" nie tyle jest jego „wielkość" (nieśmiertelna sława), ile raczej „niepewność losu”. W tym też tkwi źródło pytań o istotę człowieczeństwa: „pytamy o istotę człowieczeństwa tylko dlatego, że źródłem człowieczeństwa jest cierpienie niepewności swoiste dla śmiertelnych"36. Przy czym Herbert efekt ten wzmacnia przywołaniem idei Norwida: „pięknem globu tego - niedostatek" (Promethidion).

36 Tamze. 